Volume and Issues Obtainable at Center for Sustainability Research and Consultancy
Journal of Accounting and Finance in Emerging Economies
ISSN: 2519-0318 \& ISSN (E): 2518-8488
Volume 7: Issue 3 September 2021
CSRᄃ
Journal homepage: www.publishing.globalcsrc.org/jafee

\title{
Work Engagement as a Consequence of Work Overload and Intimidation: The Moderating role of Spiritual Leadership and Organizational Climate
}

Ayesha Bakhtawar, Air University (AUMC), Multan Campus.

*Muhammad Adnan, Azteca University (UA), Mexico. Universidad Central de Nicaragua, Republic of Nicaragua (North America). National College of Business Administration \& Economics (NCBA\&E) Lahore, Multan Sub-campus, Pakistan

Zainab, PhD Scholar, Putra Business School, Malaysia

*Corresponding author's email: Muhammad Adnan, dr.adnanmalik1989@gmail.com

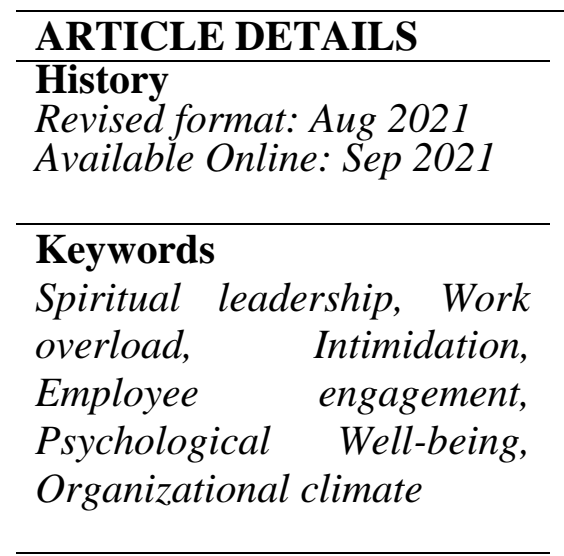

JEL Classification

$M 1, M 2$

\begin{abstract}
Purpose The purpose of the study seeks to proposed and test a research model that investigates impact of work-overload on employee engagement and employee psychological wellbeing via mediating role of intimidation and moderating role of spiritual leadership and organizational climate by employing moderation-mediationmoderation model
\end{abstract}

Design/Methodology/Approach: The data was collected from 351 pharmaceutical employees working as sales force. The study issuing convenient sampling technique. Smart PLS-SEM was used for data analysis.

Findings: The result of SEM findings revealed that spiritual leadership fails to moderate the relationship in the perspective of existing framework whereas organization climate moderates the relationship between intimidation and employee engagement, which indicates that even the intimidated employees got engaged in their work in the presence of supportive organization climate.

Implications/Originality/Value: The study framework and methodology contribute in the existing literature and creates future horizons for the scholars. Longitudinal data might be valuable in future studies for establishing causal extrapolations between study variables. Future studies could benefit from incorporating cross-cultural study. Our insights can even be extended to employees in plenty of other workplaces wherein everyday organizational interactions are necessary 


\section{Introduction}

In today's competitive business environment, work overload is a critical concern (García-Arroyo \& Segovia, 2019). Workplace pressure or work-overload is a substantial cost to employee work behavior which leads to intimidation that has long been identified as a common element of impression management practice in the research on impression management, involves the intentional use of pressure to demonstrate one's personal strength and secure behavioral compliance in order to generate a desirable impression in the minds of others(Kimura et al., 2018a).Under certain circumstances, intimidation comes as a result of allocating an overwhelming quantity of work, whilst in others, it results in work overload. Work overload has received a lot of attention in the management area among the numerous work stressors (Kimura et al., 2018b). Workload and time pressures surpass employees' ability to do their tasks, resulting in work overload. Work overload, for example, is described by the International Labor Organization (ILO) as a major source of workplace stress and a major cause of mental health problems (ILO, 2016). Due to challenging duties and a culture of extended working hours, today's workers are completely overwhelmed at the end of the day (Kimura et al., 2018b). The stress of working from 8 a.m. to 5 p.m., for instance, has been recognized as a central source of growing medical conditions, including hyperglycemia, hypertension, psychiatric and mental health issues, joint pain, as well as other diseases (Su et al., 2018). Keeping people healthy and able to work insane hours efficiently is a major concern for personnel management. Employee engagement at work is one measure of healthy mental wellbeing (Uchechukwu et al., 2020). Employee well-being, both physically and psychologically, is critical, and studies have shown that it has an impact on organizational progress. Employees who feel good and deal with less stress at work and at home, for example, are generally more engaged with their employment, which can have also impact on their well-being and the business progress (Dinh, 2020).The work behaviors of employees reflect their dedication, loyalty, and positive disobedience. When employees are under stress, their output level may be low or high as compared to the normal production rate? When employees are unproductive, it takes a longer time to complete the job, which increases the cost to the employer. Employees' productivity directly affects an organization's performance in terms of growth and profitability (Naru \& Rehman,2020).

Globally, 27\% of the staff is Highly Engaged, 38\% are Moderately Engaged, 21\% Passive, $14 \%$ Actively Detached (AON, 2018). Though, high productivity and the happiness of the employees are the results of better employee engagement ("Organizational Happiness Index (OHI): Conceptualization and Operationalization of Measurement among Employees in Services Industry,” 2016; Rich et al., 2010). It is because work engagement may create motivation among employees and is measured as a motivational construct that gives various optimistic outcomes. Work engagement is well-defined as a self-determining and prevalent motivational psychosomatic condition with a tri-factor arrangement (Babic et al., 2020; Schaufeli et al., 2006).Despite the fact that the aspects of engaging at work, job performance, and psychological well-being have critical interactions amongst each other, as well as a tendency to demonstrate constancy among people over time, among practitioners and academics, employee engagement is their foremost focus(Ahmed, 2019; Uchechukwu et al., 2020). This is due to the fact that engaged workers are likely to have higher levels of motivation and commitment in their respective occupations and organizations. The drive and outcomes of employee behavior cause employee work engagement as well as contribute to the improved mental well-being. This considerable emphasis is directed towards the development of potential benefits of work engagement, such as better organizational performance (Ali \& Zia-ur-Rehman, 2020), organizational citizenship behavior(Gupta et al., 2017), organizational obligation (Hanaysha, 2016), and individuals' job satisfaction ((Flores et al., 2021).Conversely, according to COR(conservation of resource theory) we acknowledge a number of personal resources can contribute to mitigating the negative effects of the workload (Prapanjaroensin et al., 2017), we emphasized spiritual leadership and organizational climate as moderator in our study to determine employee engagement and psychological well-being. According to Lazarus' transactional theory, the autonomous personal resources reduce the negative effect of work-overload (Lazarus, 1991). While empirical research have focused on the moderating effects of job resources, evidence for the interplay between personal resources and job demands is scarce, as Bakker \& Demerouti, (2018) pointed 
out that personal resources are people's perceptions of their capacity to effectively organize and influence employees surroundings, despite difficult situations (TRUONG et al., 2021). Moreover, it is important to check moderation effects in these scenarios the study aim to take organizational climate as moderator it is also a depiction of conservation resources theory that if employee having enough resources, he takes stress as motivation and remain engaged with their work. On the other hand, moderating variable spiritual may sound as positive leadership and one can be more mentally healthy and happy at workplace if he/she is internally satisfied religiously (Zou et al., 2020). This study expands the scant literature by determining the moderating roles in regard to work-overload and its consequences. Overall, this study contributes to workplace behavioral research by providing strategies to improve employee engagement levels and their psychological wellbeing in the pharmaceutical sector.

\section{Literature Review}

\section{Work-overload and employee engagement}

According to Taylor et al., (1997), employees who feel obligated to work too long and too hard at too many everyday jobs report more stress, have poorer health habits, and account for more health grievances than workers who are not subjected to work- overload. Today's workplace demands its employees be highly efficient and must be able to maintain productivity. To meet this need, workers face a workload, a condition that presents some real challenges for employees, including the company(García-Arroyo \& Segovia, 2019). The apparent work burden is tied to an employee's engagement level. An engaged employee, thus, will be more satisfied with one's professional role and performance at work, in contrast to disengaged employees who will display higher levels of anxiety(Ugwu \& Onyishi, 2020). An empirical study by Fairbrother \& Warn( 2003) acknowledged that the high intensity of stress at work decreases the employee engagement with the corporation and increases the logical reasoning to depart from the organization (Chen et al., 2011). Based on the preceding, we hypothesize the following:

H1: There is a relationship between work overload and employee engagement.

\section{Work Overload and Employee Psychological Well-being}

Work overload is a principal aspect of empirical studies of stress(García-Arroyo \& Segovia, 2019).Psychological wellbeing is linked to flexible and creative thinking, pro-social behavior, and overall health of the individual(Huppert,2009).It is the combination of feeling happy and executing well. Therigorous psychological health associated issues reported by employees in organizations of industrialized countries are the consequence they are facing psychological anxiety and stress which are the link to excessive job strains and challenges at the workplace. (WHO, 2007) the workload is the top of the stressor. Organizations ask employees to do more work and cut resources, lack of capital and inadequate recruitment can make it difficult for employees to get their job done properly. (Justice, 2018).Work pressures like work burden and physical grievances reported by the employees (i.e., sciatica, annoyance, eye strain, diminishing sleep, faintness, fatigue, craving loss and intestinal glitches). All of these job stressors comprised in (Nixona et al., 2011) meta-analysis (i.e., relational- clash, lack of control, structural restraints, title role uncertainty, title role conflict, working periods, and workoverload) by a multiple degree of corporal indications. Thus, we formulated the hypothesis that:

H2: Work- overload has a negative correlation with employee's psychological wellbeing.

\section{Intimidation Affects Employees' Engagement}

Intimidation often well - define as negative irritating behavior at the workplace. (Lamontagne, 2010; Musselman et al., 2005; Nadzam, 2009). Employees who perceive that they are getting negative conduct in the business organization and their engagement towards work get reduce, so they are more overly exposed towards getting anger, revengeful and pull out commencing their character. Reliable by means of the directions of a tradeoff, these displeased staffs keep behaving in divergent ways, for instance, suppression power, coming late at the office, captivating extensive pauses more than that are 
permissible, and others negative conducts like this(Shantz et al., 2013).Nobody likes to work in an intimidating and non-productive atmosphere, particularly if you have bullying or bullying, which has a health and productivity impact. Management by intimation may be short-term. Anxiety does not enable employees to weaken them as a point of work engagement. In a workplace environment based on fear, an employee is no longer concerned about the company's goals or purposes. Servicing, work performance, and quantity are no longer important to them(Chawla et al., 2020). Furthermore, tiredness and depersonalization were found to be associated to devotion and vigor in an indirect manner. Thus we formulated:

H3: There exists a reciprocal relation between intimidation and employee engagement.

\section{Intimidation Effects Employee Psychological Well-Being}

Intimidation which is also named as frightening is a premeditated performance that "would cause a person of ordinary sensibilities" to terror or doing harmful acts for others. International labor organization ILO conveyed that forcefulness at work mainly intimidation is the reason for musculoskeletal abnormalities which is getting attention in occupational health and safety practices now (International Labour Organization, 2016). A current study explores that mental strain is mediated in this whole process. (M. C. Bolino \& Turnley, 2003; Jones \& Pittman, 1982). Nixona, Mazzolab, Bauera, Kruegerc, \& Spectora, (2011) studied about work pressures like work burden and physical grievances reported by the employees. (i.e., sciatica, annoyance, eye strain, diminishing sleep, faintness, fatigue, craving loss, and intestinal glitches). It is shown empirically by different studies that Intimidation caused by job demands may lead to psychological withdrawal. So, we formulated the hypothesis:

\section{H4: Intimidation positively effects employee psychological well-being.}

\section{Intimidation Mediates the Relationship between Work -Overload and Employee Engagement}

Lack of social support will lead to employee stress and finally affect their occupational health and wellbeing. Today work overload burdens its employees to be greatly efficient and must be able to maintain productivity and they feel aggressive (Frone, 2008; Kimura et al., 2018b). Correspondence to the theory of general strain when employees feel a intimidation to themselves so they get involved in handling strategies and to cope that stress they behave divergently towards others and get intimidated (AGNEW et al., 2006). The apparent work burden is tied with an employees' engagement level. Work engagement is thoroughly associated with workers' physical and mental well-being. (Kahn,1990). Employees who perceive that they are getting negative conduct in the business organization, so they are more overly exposed towards getting anger, revengeful and pull out commencing their character so it decreases their commitment and passion towards their work (Kimura et al., 2018b).

H5: Intimidation mediates the relationship between work -overload and employee engagement

\section{Intimidation Mediates the Relationship between Work Overload and Employee Psychological Well-Being.}

Intimidation is a forceful approach that involves the use of threatening or harassment in a way to act menacing and influential (Harris et al., 2013). According to Chawla et al., (2020), modern organizations value teamwork and homogeneity, and individuals who intimidate and harass coworkers may be viewed as a problem rather than an asset, and hence receive lower performance ratings. Likewise, experts believe that people are frequently furious and suspicious of all those who try to influence and bully them (Arifin et al., 2019). Correspondence with Lazarus transactional theory of stress the severe psychological health associated issues reported by employees in organizations of industrialized countries are the consequence they are facing psychological anxiety and stress which are the link to excessive job strains and challenges at the workplace. (WHO, 2007). It is shown empirically by different studies that Intimidation caused by work-overload may lead to psychological withdrawal. So, we formulated that:

H6: Intimidation mediates the relationship between work -overload and employee psychological well- 
being.

\section{Organizational Climate Exists as a Moderator between Work-Overload and Intimidation.}

There are many aspects of workplace settings that are assumed directly or randomly by the workforce, which is regarded to have a significant influence on employee behavior (McMurray et al., 2010). Employees in today's workplace must be very efficient and capable of maintaining productivity. Workers are strained in order to meet this need, which poses some serious issues for the organization (2016, Egbert). Fear of punishment is a sort of intimidation that aims to increase the severity of formal punishment among an organization's employees (Lara, 2006). Businesses have a proclivity for provoking or preventing divergence from their way of life. Einarsen \& Skogstad, (1996) indicate if a behavior is understood, abided by, or acknowledged based on workplace principles such as whether or not employees can self-control divergent acts at work.

So, we formulate a hypothesis:

H7: Organizational climate act as a moderator between the workload and intimidation

\section{Organizational Climate Moderates the Relationship between Intimidation and Employee Engagement.}

The supported organizational environment creates desire which is mandatory to influence and increase the engagement level of employees working there. Outside income, employees may expect to advance profits from their workplaces such as gratitude towards attainment, occupation expansion and development, and pleasant-sounding organizational environment and supportive executive chic. It is believed that companies that offer a better work-life balance and hospitable working environments will likely enjoy high profitability and the retention of the greatest human capital. Essentially, the organizational climate, often known as the business climate, is the process of outlining an institute's "culture". It leads to the concept of workplace strategy. It is a set of work environment attributes assumed directly or indirectly by the workforce to be a primary driver in affecting employee behavior (McMurray et al., 2010). So we formulated the hypothesis:

H8: Organizational climates moderate the correlation between intimidation and employee engagement.

\section{Spiritual Leadership Moderates the Correlation between Workload and Intimidation}

Spiritual leadership is essential for effecting change and advancing the success of knowledge enterprises. Prior studies have also shown a significant relationship with workplace divergent behavior. Fear of punishment is an intimidation paradigm that intends to extend the degree of formal penalty among the organization's workers. (Lara,2006). The impression of difficulty or proficiency that comes from executing the work was determined to be an inner drive (Keaveney\& Hunt, 1992). In any job, inherent drive is crucial. Other issues can be addressed by being stimulated and achieving personal pleasure. Employees who are associated with elevated degrees of workplace spirituality may be more likely to reject threatening behavior and renounce immediate benefits in order to reveal greater sense of meaning and purpose at work (Fry, 2003; Hsu et al., 2011). As a result, spiritual leadership plays a unique role as a buffering device. Spiritual leadership can boost both employee work engagement and organizational citizenship behaviors (Ahmad \& Omar, 2014).

H9: Spiritual leadership moderates the correlation between workload and intimidation

Yang et al. (2019) emphasized the inner self. He believes that the working spirit of employees cannot be neglected because it is what makes an individual human. Transmitting an organization's knowledge and practice is a major challenge (Mariwa et al., 2021). In order to make the businesses progress, the business models and psychological well-being of an employee must include the element of spirituality for creating pro-social behaviors in the organization, increasing performance and doing sustainable practices. Saks, (2011) projected framework of spirituality at job and employee engagement in which tri- 
scopes of spirituality are definitely related to employee engagement and not involve in negative acts Workers feel harmless in settings that remained considered by the directness and supportive. Employees have spiritual needs same as their other needs. (Singh \& Chopra, 2016) so we formulated the hypothesis:

H10: Spiritual leadership moderates the correlation between intimidation and employee engagement.

H11: Spiritual leadership moderates the relationship between intimidation and employee psychological well-being.

\section{Transactional theory}

Lazarus's theory of stress-strain provides a transaction model of stress and confrontation is the context for assessing the process of dealing with stressful happenings. Stress-full experiences are interpreted as a person-environment operation. These transactions depend on the influence of external stressors. This is interceded first by the impost of the strain by the individual and then by the social and traditional means in his or her personality.

When the individual is confronted with frustration, he will assess the latent threat (preliminary assessment). A preliminary assessment is a judgment of the prominence of an event, that is, stress, optimism, controllable, challenging or immaterial. In the face of possible stressors, the second assessment is an assessment of people's responses to resources and choices(Kimura et al., 2018b; "Lazarus Theory," 2020). According to the theory, people do not feel strained when they believe they have enough personal resources. Individuals, on the other hand, suffer a strain when they believe the personal coping resources are limited, thus they engage in a coping approach as one part of stress management is dealing with the source of the stress (problem-focused coping).These coping techniques include intimidation, in which the employee addresses the causes of stress with aggressive ways to undermine the circumstances and resolve the issue(Sivan-Donin et al., 2019).

And according to "Organ. Stress A Rev. Crit. Theory, Res. Appl.,"( 2012) job strain such as intimidation is a sort of behavioral strain, which is a way for individuals to manage stress by either eliminating the stressor or minimizing the unpleasant feelings generated by it (Penney \& Spector, 2005). Intimidation is defined by M. Bolino et al., (2016a) as strategy of an individual to "let others know that if they have been pushed too far, they can make life harder, deal aggressively with individuals who get in their way, or use vigorous behavior to get coworkers to act properly. "They also claimed that people who utilize intimidation may create resistance or contempt in the end (M. Bolino et al., 2016b).

\section{Conservation of Resource Theory}

The Conservation of Resource Theory (COR) provides a structure for understanding the stress response and suggests that stress is the result of threats or conditions related to the actual loss of valuable resources. It has been found to be a reliable basis for understanding the processes involved in the experience, addressing and overcoming long-lasting and distressing stress.

In addition, the desire to protect and acquire these valuable resources motivates human behavior against stress. Agreeing to the COR theory, the damage is more important than gain, and damage causes damage.

\section{General strain theory}

General strain theory suggests that whenever a person confronted with an amplified level of stress like work overload, they receive a highly deleterious incitement and involves deviant actions and aggressive behavior with others. The person got angry when he or she got unable to achieve their goal(Agnew, 1992).

\section{Research Framework}




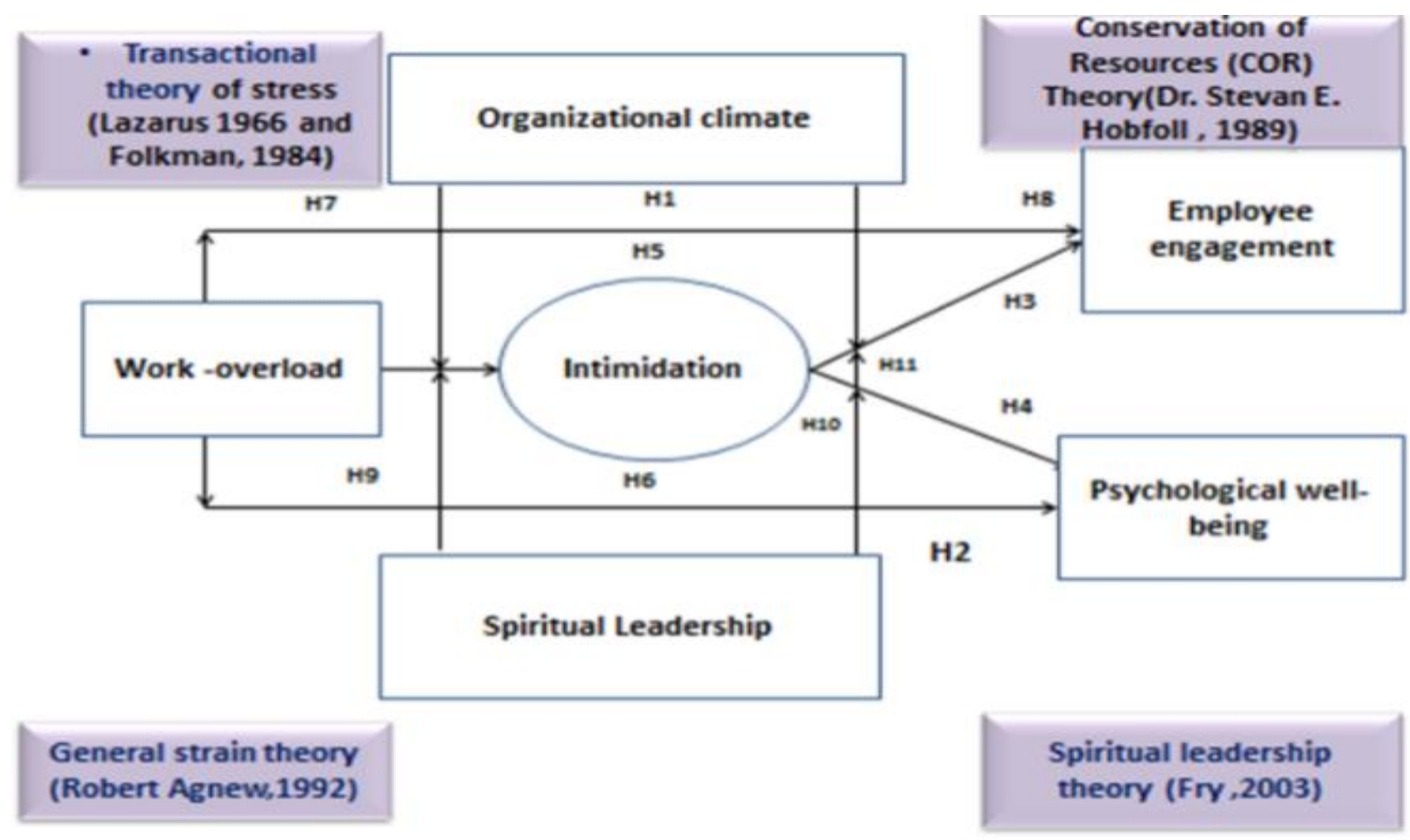

Figure \# 1: Research Framework

\section{Methodology}

\section{Respondents and the procedure}

We employed a sample matching supervisor to carry out a quantitative analysis of a questionnaire survey to put our technique to the testing. In order to ensure a proper representation of sales force, we have requested replies from numerous pharmaceutical businesses. The companies were picked on the basis of their commercial status and because they supplied predominantly business clients. The final sample includes 350 corresponding supervisor salesperson dyads, with 150 salespeople and 100 supervisors. Participants received no compensation for providing their responses.

\section{Measurement}

The survey instrument was initially written in English. The scales were adopted from different authors. Employees responded on work overload, intimidation, spiritual leadership, corporate atmosphere, employee engagement, and psychological well-being. Whereas their immediate managers gave information on their subordinates' sales performance and level of workplace involvement overwhelming workload. We used the five-point Likert scale ranging ( $1=$ strongly disagree to $5=$ strongly agree).

\section{Findings}

\section{Descriptive Statistics}

The demographics of respondents showed descriptive data (table \#1\&2) indicating just $06 \%$ of those who participated in the research were women. The responders were usually between 26 and 35 years of age. The size of the respondents received a diploma with the highest academic qualifications, 54 per cent. Of the 351 participants, $75 \%$ have had more than two years of solid job experience. Lastly, most of the respondents $98 \%$ were belong to the private sector

\section{Testing of Hypotheses}

We conducted a conditional process analysis utilizing the SPSS Release 2.16 process. Age and gender of the salesperson were used as control variables. For data analysis, the Partial Least Squares Structural Equation Modeling (PLS-SEM) method was used(Hair et al., 2011)..Hypothesis 1results that work- 
overload have an insignificant relationship with employee engagement of sales employees of the pharmaceutical sector. Figure demonstrates $(\beta=-0.059, \mathrm{t}=1.36, \mathrm{p}>0.17)$. Hypothesis 2 asserted that work-overload has a statistically significant association with employee psychological well-being $(=-$ $0.486, \mathrm{t}=3, \mathrm{P}>0.05$ ), as indicated by the statistically significant effect of their interaction.

Hypothesis 3 asserted that there is an insignificant association between intimidation and employee engagement which tells us that being coercing at work does not impact the commitment level of employees $(\beta=0.001, \mathrm{t}=0.015 \mathrm{p}>0.05)$ Hypothesis 4 predicted that intimidation is significantly related to employee engagement. Results (Figure 8) demonstrate the negative relationship between intimidation and work engagement $(\beta=-0.171, \mathrm{t}=3.300, \mathrm{p}<0.05)$. Hypothesis 5 resulted that intimidation having a direct path and fully mediated the relationship between work-overload and employees engaging behavior as it predicted that if an employee will feel work overburden he will lead towards strain and the employee will behave violently so his engagement towards work will get $\operatorname{reduced}(\beta=0.182, \mathrm{t}=4.638, \mathrm{p}$ $<0.05)$.Hypothesis 6 resulted that there exists a partial mediation association between the work overload and employee's mental/psychological wellbeing so if the worker will get frustrated so he or she will experience stress and become psychologically ill $(\beta=0.106, t=4.262 p<0.05)$.

To probe the moderating effect of spiritual leadership and organizational climate Hypothesis 7 which explains that the environment of an organization will have a relationship with employee engagement and if the climate of the organization will be supported so the employee will take their stress as motivation and work with commitment. $(\beta=0.248, \mathrm{t}=3.562 \mathrm{p}<0.05)$.

Similarly, Hypothesis 8 predicted that spiritual leadership is significantly related to employee engagement. Results demonstrate a negative significant association among SL and employee engagement $(\beta=-0.624, \mathrm{t}=11.235, \mathrm{p}<0.05)$ supports hypothesis 7 . Furthermore, Hypothesis 9 predicted that spiritual leadership is insignificantly moderated between work-overload and intimidation. Results demonstrate a positive relationship between market SL and work engagement $(\beta=0.028, \mathrm{t}=$ $0.345, \mathrm{p}>0.05)$. Hypothesis 10 predicted that spiritual leadership is insignificantly between work engagement and intimidation. Results demonstrate no moderation among them $(\beta=-0.014, \mathrm{t}=0.313$, $\mathrm{p}>0.05)$. Hypothesis 11 predicted that spiritual leadership having no moderation between intimidating behavior and employee psychological wellbeing which tells us that spiritual they will not enhance the mental wellbeing of employees at a job $(\beta=-0.033, \mathrm{t}=0.818, \mathrm{p}>0.05)$.

Overall, the results mostly supported the framework hypothesis except for few hypotheses in which work overload not directly affect employee engagement. Else spiritual leadership showed no moderating effect in this current study but there exists a significant relationship for the second moderation organizational climate.

Table 01: Descriptive Statistics

\begin{tabular}{|c|c|c|c|c|c|c|c|c|c|c|}
\hline Descriptive Sta & tistics & $\begin{array}{l}\text { Minimu } \\
\text { m }\end{array}$ & $\begin{array}{l}\text { Maximu } \\
\mathbf{m}\end{array}$ & Mean & & $\begin{array}{l}\text { Std. } \\
\text { Deviation }\end{array}$ & Skewnes & & Kurtosi & \\
\hline & Statisti & & & Statisti & Std. & & & Std. & & Std. \\
\hline & $\begin{array}{l}\text { c } \\
350\end{array}$ & Statistic & Statistic & $\begin{array}{l}\text { c } \\
10600\end{array}$ & $\begin{array}{c}\text { Error } \\
01271\end{array}$ & $\frac{\text { Statistic }}{23783}$ & $\frac{\text { Statistic }}{3721}$ & Error & $\frac{\text { Statistic }}{11917}$ & Error \\
\hline $\begin{array}{l}\text { Gender } \\
\text { City }\end{array}$ & 350 & 1.00 & 5.00 & 3.6629 & .06975 & 1.30485 & -.773 & .130 & -.543 & .260 \\
\hline $\begin{array}{l}\text { Work } \\
\text { Experience }\end{array}$ & 350 & 1.00 & 5.00 & 2.9457 & .07836 & 1.46592 & .171 & .130 & -1.353 & 260 \\
\hline Education & 349 & 1.00 & 2.00 & 1.4957 & .02680 & .50070 & .017 & .131 & -2.011 & 260 \\
\hline Age & 350 & 1.00 & 4.00 & 1.4543 & .03443 & .64406 & 1.304 & .130 & 1.365 & 260 \\
\hline Organization & 350 & 1.00 & 3.00 & 1.0229 & .00896 & .16772 & 8.138 & .130 & 73.421 & 260 \\
\hline $\begin{array}{l}\text { Type } \\
\text { Valid } \\
\text { (listwise) }\end{array}$ & N349 & & & & & & & & & \\
\hline
\end{tabular}


The descriptive statistics of the model has been shown in the above table which demonstrates the minimum and maximum scores, the value of the standard deviation and mean. The mean score of this study ranges from 1.06 to 1.0229 and standard deviation of the variables were ranges from 0.1271 to .00896. Moreover, the ranges of skewness and kurtosis were also seen in this study.

\section{Measurement Model}

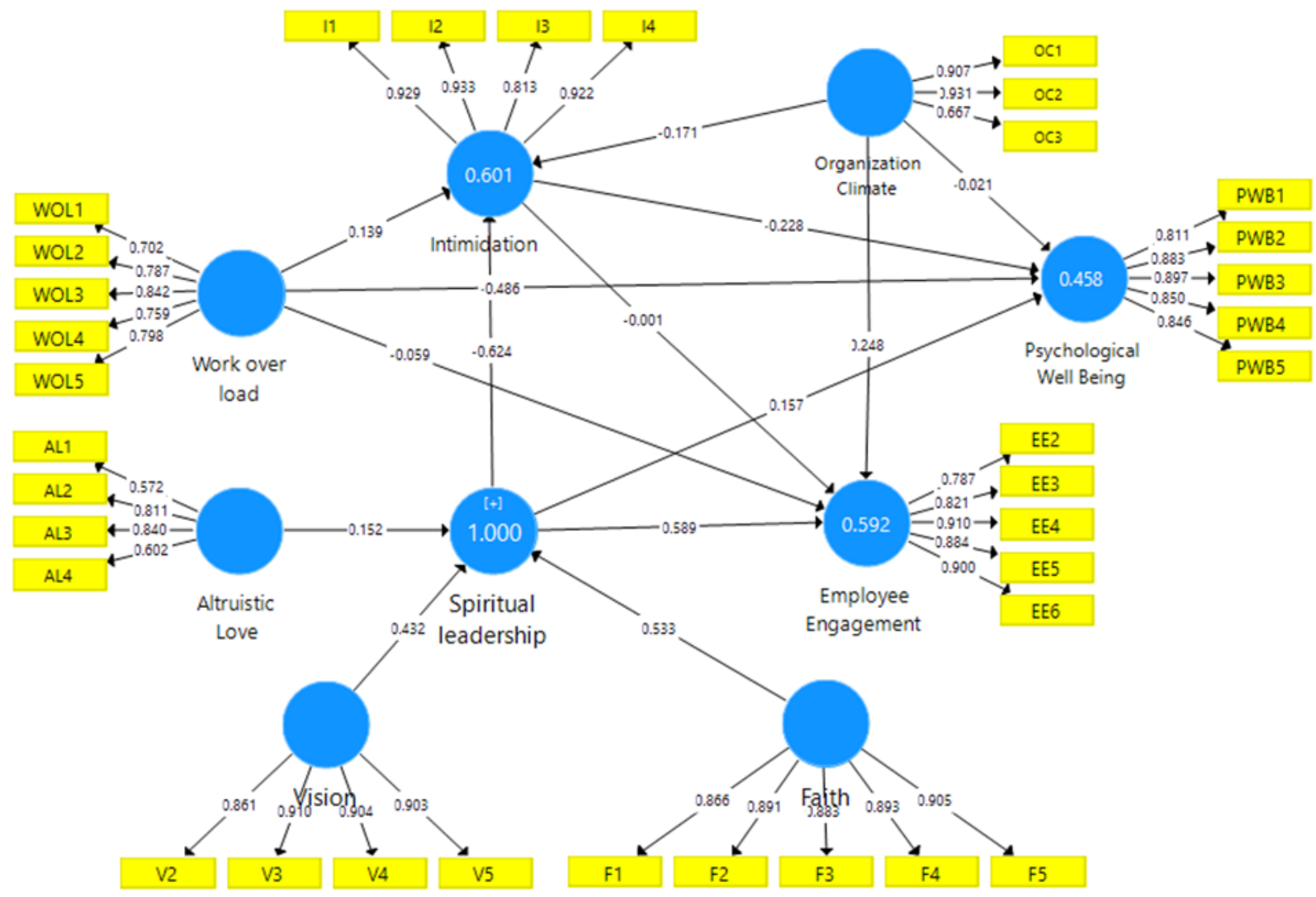

Figure 01: Measurement Model

Table 2: Measurement Model Summary

\begin{tabular}{|c|c|c|c|c|c|}
\hline Constructs & Loadings & Cronbach alpha & Composite Reliability & AVE & Outer VIF \\
\hline \multirow{5}{*}{$\begin{array}{l}\text { Employee } \\
\text { Engagement }\end{array}$} & EE2 & 0.912 & 0.935 & 0.742 & 1.934 \\
\hline & EE3 & & & & 2.221 \\
\hline & EE4 & & & & 3.597 \\
\hline & EE5 & & & & 3.425 \\
\hline & EE6 & & & & 3.674 \\
\hline \multirow{4}{*}{ Altruistic Love } & AL1 & 0.682 & 0.804 & 0.513 & 1.348 \\
\hline & AL2 & & & & 2.004 \\
\hline & AL3 & & & & 1.735 \\
\hline & AL4 & & & & 1.127 \\
\hline \multirow{5}{*}{ Faith/ hope } & F1 & 0.933 & 0.949 & 0.788 & 2.802 \\
\hline & F2 & & & & 3.243 \\
\hline & F3 & & & & 3.033 \\
\hline & F4 & & & & 3.378 \\
\hline & F5 & & & & 3.634 \\
\hline \multirow{4}{*}{ Vision } & V2 & 0.917 & 0.941 & 0.801 & 2.675 \\
\hline & V3 & & & & 3.501 \\
\hline & V4 & & & & 3.524 \\
\hline & V5 & & & & 3.521 \\
\hline
\end{tabular}




\begin{tabular}{|c|c|c|c|c|c|}
\hline \multirow{4}{*}{ Intimidation } & I1 & 0.921 & 0.945 & 0.811 & 3.800 \\
\hline & I2 & & & & 3.970 \\
\hline & I3 & & & & 1.976 \\
\hline & I4 & & & & 3.723 \\
\hline \multirow{3}{*}{$\begin{array}{l}\text { Organizational } \\
\text { Climate }\end{array}$} & OC1 & 0.798 & 0.879 & 0.711 & 2.383 \\
\hline & OC2 & & & & 2.59 \\
\hline & OC3 & & & & 1.361 \\
\hline \multirow{5}{*}{$\begin{array}{l}\text { Psychological } \\
\text { Well-Being }\end{array}$} & PWB1 & 0.910 & 0.933 & 0.736 & 2.074 \\
\hline & PWB2 & & & & 3.436 \\
\hline & PWB3 & & & & 3.799 \\
\hline & PWB4 & & & & 2.626 \\
\hline & PWB5 & & & & 2.446 \\
\hline \multirow{5}{*}{ Work Overload } & WOL1 & 0.840 & 0.885 & 0.607 & 1.698 \\
\hline & WOL2 & & & & 1.893 \\
\hline & WOL3 & & & & 2.043 \\
\hline & WOL4 & & & & 1.809 \\
\hline & WOL5 & & & & 1.703 \\
\hline
\end{tabular}

According to Hair Jr. et al. (2014), contrasting Cronbach's alpha, CR does not undertake an equivalent pointer loading of the construct. CR varies between 0 and 1; the threshold value should not be lower than 0.60 but the value of 0.70 and above is most desirable (Hair et al., 2012). Accordingly, CR value between 0.6 and 0.7 indicates average internal consistency, while a value between 0.70 and 0.90 is regarded as more adequate. In the model assessment, the measurement model was considered to confirm reliability and rationality. In link with the opinions of Vinzi et al., (2010) who gave the rule of thumb for outer loading, the outer loading must be .50 and above. Next, the average variance removed, must be more than 0.50 . However, in factor loading the value below 0.50 need to be erased one by one starting with the lowermost value, as it increases the excellence of overall data, this technique is also recommended by (F. Hair Jr et al., 2014). Although this research considered only Confirmatory factor analysis (CFA) by employing Smart PLS 3.2.7 (Henseler et al., 2014). As suggested by Hair et al. $(2010,2014)$, convergent validity is attained when the factor loading of all the indicators are more than 0.50 and not a single loading of whichever measurement from supplementary variable has a greater loading than the one which thinks to measure. The findings highlighted that out of 33 items, 4 were deleted as their loadings were less than the cutoff value of 0.50 . Thus, rest of the model left with 29 items which are within the range of $20 \%$ deletion of lower factor loadings and rest of the loadings were retained ranging from 0.510 to 0.953 (F. Hair Jr et al., 2014).

Table 3: Discriminant Validity

\begin{tabular}{|c|c|c|c|c|c|c|c|c|}
\hline Constructs & $\begin{array}{l}\text { Altruistic } \\
\text { Love }\end{array}$ & $\begin{array}{l}\text { Employee } \\
\text { Engagement }\end{array}$ & Faith & Intimidation & $\begin{array}{l}\text { Organization } \\
\text { Climate }\end{array}$ & $\begin{array}{l}\text { Psychological } \\
\text { Well Being }\end{array}$ & Vision & $\begin{array}{l}\text { Work } \\
\text { over } \\
\text { load }\end{array}$ \\
\hline Altruistic Love & 0.716 & & & & & & & \\
\hline $\begin{array}{l}\text { Employee } \\
\text { Engagement }\end{array}$ & 0.543 & 0.862 & & & & & & \\
\hline Faith & 0.424 & 0.698 & 0.888 & & & & & \\
\hline Intimidation & -0.320 & -0.592 & $\overline{-}-718$ & 0.900 & & & & \\
\hline $\begin{array}{l}\text { Organization } \\
\text { Climate }\end{array}$ & 0.365 & 0.578 & 0.501 & -0.536 & 0.843 & & & \\
\hline $\begin{array}{l}\text { Psychological } \\
\text { Well Being }\end{array}$ & 0.123 & 0.408 & 0.383 & -0.488 & 0.288 & 0.858 & & \\
\hline Vision & 0.354 & 0.610 & 0.540 & -0.730 & 0.499 & 0.470 & 0.895 & \\
\hline Work over load & -0.015 & -0.245 & $\overline{-} 0.208$ & 0.316 & -0.211 & -0.589 & -0.262 & 0.779 \\
\hline
\end{tabular}

Discriminant validity was obtained by associating the correlation among the latent constructs with the square root of AVE as suggested by (Fornell \& Larcker, 1981b). Furthermore, to assess the discriminant validity, Fornell \& Larcker, (1981a) recommended the use of the average variance extracted with a score of 0.50 or more. To investigate the discriminant validity this research considered discriminant validity to confirm the external consistency of the model. However, the comparison between the suppressed 
constructs as explained in Table 8 summarize the square root of AVE of the concepts: Work overload $=0.799$; Intimidation $=0.99 ;$ Spiritual leadership $=0.822 ;$ Work engagement $=0.751$; Organizational climate $=0.843$; Psychological Well Being=0.858.

Table 04: Hypothesis Testing

\begin{tabular}{|c|c|c|}
\hline Hypothesis & Statement & Decision \\
\hline H1 & $\begin{array}{l}\text { There is a relationship between work overload and employee } \\
\text { engagement. }\end{array}$ & Not Supported \\
\hline $\mathrm{H} 2$ & $\begin{array}{l}\text { There is a relationship between work-overload and employee } \\
\text { psychological well-being. }\end{array}$ & Supported \\
\hline $\mathrm{H} 3$ & Intimidation effects employee engagement. & Not Supported \\
\hline $\mathrm{H} 4$ & Intimidation effects employee psychological well-being & Supported \\
\hline H5 & $\begin{array}{l}\text { Intimidation mediates the relationship between work -overload and } \\
\text { employee engagement. }\end{array}$ & Supported \\
\hline H6 & $\begin{array}{l}\text { Intimidation mediates the relationship between work -overload and } \\
\text { employee psychological well-being. }\end{array}$ & Partially supported \\
\hline H7 & $\begin{array}{l}\text { Organizational culture moderates the relationship between workload } \\
\text { and intimidation. }\end{array}$ & Not supported \\
\hline $\mathrm{H} 8$ & $\begin{array}{l}\text { "Organizational culture moderates the relationship between } \\
\text { intimidation and employee engagement. }\end{array}$ & Not Supported \\
\hline H9 & $\begin{array}{l}\text { "Spiritual leadership moderates the relationship between workload and } \\
\text { intimidation, }\end{array}$ & Not Supported \\
\hline H10 & $\begin{array}{l}\text { "Spiritual leadership moderates the relationship between intimidation } \\
\text { and employee engagement. }\end{array}$ & NOT Supported \\
\hline H11 & $\begin{array}{l}\text { Spiritual leadership mediates the relationship between intimidation } \\
\text { and employee psychological well-being }\end{array}$ & Not Supported \\
\hline
\end{tabular}

\section{Statistical Analysis}

Prior research on influence strategies and political behavior has found that undesired types of behavior, such as intimidation, are common in workplaces, and that such behavior is viewed negatively by supervisors and employees. The findings demonstrated that spiritual leadership does not have a significant moderating effect on the relationship between work-overload and employee engagement and psychological well-being. On the other hand, OC can be used to discourage individuals from engaging in intimidation, but it is insufficient for coping with resource depletion induced by work overload. Findings suggest that employees who work in a sufficiently supportive environment are less inclined towards intimidation. Here, our second moderation works best, i.e., OC showed a significant relationship with employee engagement and psychological wellbeing, so that the findings explore that the climate of the organization is good and supported, so that employees feel engaged and happy at their work. Supportive organizational climate acts as a protective factor against risk factors. As the state when individuals face a high level of stress and loads of work (Kimura et al., 2018b).

\section{Conclusion}

This empirical study analyzes the relationship between the variables such as work-overload, spiritual leadership, organizational climate intimidation, and work engagement and employee psychological wellbeing. The research reveals that if the employee feels stress at work, they get involved in some sort of divergent behaves with others and try to show power to harm others and eventually lose their passion to do work and their healthiness. The study has taken organizational climate and Spiritual Leadership as moderators and a MOD-MED-MOD analysis has been done. The finding shows that spiritual leadership did not work very well in this context and there exist no moderation results This result shows that there exists a full mediation of intimidation in the relationship between work overload and work engagement and partial mediation and significance with employee psychological well-being. Moreover, it was shown by current findings that spiritual leadership and organizational climate moderates the relationship between intimidation with work engagement and psychological well-being but it does not play moderating role between work overload and intimidation After the examination of this study it has been concluded that if the environment of the company is supported then employees will take their workoverload stress as motivation to them and will not engage in aggressive negative behavior and it will 
enhance their engagement towards their jobs.

\section{Managerial Implications}

Managers need strategies to cope with employee engagement and employee mental wellbeing issues. Employee psychological wellbeing enhances corporate wellness and creates a healthy environment. This study has provided useful insights to policymakers, practitioners, academicians, and management in pharmaceuticals as well as other related industries. Our findings are extremely important to sales management for two reasons. For instance, many salespeople's daily work involves human interactions with peers or colleagues (e.g., short meetings, brief discussions for exchange of information, regular reports, and so forth), which can escalate to intimidation. Moreover, the salesperson's work has gotten more demanding, sophisticated, and difficult, requiring work to be done over a longer period of time.

\section{Limitations and Future Paths for Research}

Although this study contributes significantly to the literature as well as it keeps several shortcomings. These limits necessitate a "with reservations" conclusion, but they also open up some avenues for further investigation. This study was limited to a few pharmaceutical companies in Pakistan. The research should be expanded to include more samples and any industry in Pakistan to improve the model's generalizability. Furthermore, other industries and organizations might be added in the sample to develop the value of the outcome. Future research could look into this subject in different industries. Second; our findings revealed that work overload has a direct impact on salesperson employee engagement and mental health. While the indirect approach via intimidation shows an IM influence on supervisory appraisal, the direct path may reflect the significant effect of job overload on employee engagement and psychological well-being. Future research could look into the impact of other aspects of impression management as mediation, such as Exemplification (Kimura et al., 2018b). Future research can expand on this topic by using observation, peer reports, or supervisor ratings. Future research can look into other work outcomes and behaviors. Comparison of two sectors like private and public can also be studied further. To better comprehend the process of intimidation, employee engagement and employee mental wellbeing, the contributions to the model must be increased to include emotional aspects such as surface action, deep behavior and other cognitive characteristics (Kimura et al., 2018b). Exploratory research may help the literature of intimidation and work engagement and psychological well-being. Moreover, other psychological variables may be used in the future. Although, we can extend our findings in other work contexts and industries like salesperson of industry food and beverage.

\section{References}

Agnew, R. (1992). HeinOnline -- 29 Criminology 47 1991-1992. Criminology.

AGNEW, R., BREZINA, T., WRIGHT, J. P., \& CULLEN, F. T. (2006). STRAIN, PERSONALITY TRAITS, AND DELINQUENCY: EXTENDING GENERAL STRAIN THEORY. Criminology, 40(1), 43-72. https://doi.org/10.1111/j.1745-9125.2002.tb00949.x

Ahmad, A., \& Omar, Z. (2014). Reducing deviant behavior through workplace spirituality and job satisfaction. Asian Social Science, 10(19), 107-112. https://doi.org/10.5539/ass.v10n19p107

Ahmed, U. (2019). Job Demands and Work Engagement: Call for More Urgent Empirical Attention. Annals of Contemporary Developments in Management \& HR. https://doi.org/10.33166/acdmhr.2019.02.002

Ali, S., \& Zia-ur-Rehman, M. (2020). Impact of Work Overload and Fear of Negative Evaluation on Employees Performance: Analyzing the Role of Frustration at Work Place. Global Social Sciences Review. https://doi.org/10.31703/gssr.2020(v-iii).26

AON. (2018). 2018 Trends in Global Employee Engagement: Global Employee Engagement Rebounds to Match Its All-Time High. AON.

Arifin, Z., Nirwanto, N., \& Manan, A. (2019). Analysis of bullying effects on job performance using employee engagement and job satisfaction as mediation. International Journal of Innovation, Creativity and Change.

Babic, A., Gillis, N., \& Hansez, I. (2020). Work-to-family interface and well-being: The role of 
workload, emotional load, support and recognition from supervisors. SA Journal of Industrial Psychology. https://doi.org/10.4102/sajip.v46i0.1628

Bakker, A. B., \& Demerouti, E. (2018). Multiple Levels in Job Demands - Resources Theory: Implications for Employee Well-being and Performance. Handbook of Well-Being.

Bolino, M. C., \& Turnley, W. H. (2003). Counternormative impression management, likeability, and performance ratings: The use of intimidation in an organizational setting. Journal of Organizational Behavior, 24(2), 237-250. https://doi.org/10.1002/job.185

Bolino, M., Long, D., \& Turnley, W. (2016a). Impression Management in Organizations: Critical Questions, Answers, and Areas for Future Research. In Annual Review of Organizational Psychology and Organizational Behavior. https://doi.org/10.1146/annurev-orgpsych-041015062337

Bolino, M., Long, D., \& Turnley, W. H. (2016b). Impression Management in Organizations: Critical Questions, Answers, and Areas for Future Research. In SSRN. https://doi.org/10.1146/annurevorgpsych-041015-062337

Chawla, N., Gabriel, A. S., Rosen, C. C., Evans, J. B., Koopman, J., Hochwarter, W. A., Palmer, J. C., \& Jordan, S. L. (2020). A person-centered view of impression management, inauthenticity, and employee behavior. Personnel Psychology. https://doi.org/10.1111/peps.12437

Chen, M. F., Lin, C. P., \& Lien, G. Y. (2011). Modelling job stress as a mediating role in predicting turnover intention. Service Industries Journal. https://doi.org/10.1080/02642060903437543

Dinh, L. N. (2020). Determinants of employee engagement mediated by work-life balance and work stress. Management Science Letters. https://doi.org/10.5267/j.msl.2019.10.003

F. Hair Jr, J., Sarstedt, M., Hopkins, L., \& G. Kuppelwieser, V. (2014). Partial least squares structural equation modeling (PLS-SEM). European Business Review, 26(2), 106-121. https://doi.org/10.1108/EBR-10-2013-0128

Fairbrother, K., \& Warn, J. (2003). Workplace dimensions, stress and job satisfaction. Journal of Managerial Psychology. https://doi.org/10.1108/02683940310459565

Fligstein, N., \& McAdam, D. (2011). Toward a General Theory of Strategic Action Fields. Sociological Theory, 29(1), 1-26. https://doi.org/10.1111/j.1467-9558.2010.01385.x

Flores, N., Moret-Tatay, C., Gutiérrez-Bermejo, B., Vázquez, A., \& Jenaro, C. (2021). Assessment of occupational health and job satisfaction in workers with intellectual disability: A job demandsresources perspective. International Journal of Environmental Research and Public Health. https://doi.org/10.3390/ijerph18042072

Fornell, C., \& Larcker, D. F. (1981a). Evaluating Structural Equation Models with Unobservable Variables and Measurement Error. Journal of Marketing Research. https://doi.org/10.2307/3151312

Fornell, C., \& Larcker, D. F. (1981b). Structural Equation Models with Unobservable Variables and Measurement Error: Algebra and Statistics. Journal of Marketing Research, 18(3), 382. https://doi.org/10.2307/3150980

Frone, M. R. (2008). Are Work Stressors Related to Employee Substance Use? The Importance of Temporal Context in Assessments of Alcohol and Illicit Drug Use. Journal of Applied Psychology. https://doi.org/10.1037/0021-9010.93.1.199

Fry, L. W. (2003). Toward a theory of spiritual leadership. In Leadership Quarterly (Vol. 14, Issue 6, pp. 693-727). https://doi.org/10.1016/j.leaqua.2003.09.001

García-Arroyo, J. A., \& Segovia, A. O. (2019). Work overload and emotional exhaustion in university teachers: Moderating effects of coping styles. Universitas Psychologica. https://doi.org/10.11144/Javeriana.upsy18-2.woee

Gupta, M., Shaheen, M., \& Reddy, P. K. (2017). Impact of psychological capital on organizational citizenship behavior. Journal of Management Development, 36(7), 973-983. https://doi.org/10.1108/JMD-06-2016-0084

Hair, J. F., Sarstedt, M., Pieper, T. M., \& Ringle, C. M. (2012). The Use of Partial Least Squares Structural Equation Modeling in Strategic Management Research: A Review of Past Practices and Recommendations for Future Applications. Long Range Planning, 45(5-6), 320-340. 
https://doi.org/10.1016/j.lrp.2012.09.008

Hanaysha, J. (2016). Testing the Effects of Employee Engagement, Work Environment, and Organizational Learning on Organizational Commitment. Procedia - Social and Behavioral Sciences, 229, 289-297. https://doi.org/10.1016/j.sbspro.2016.07.139

Harris, K. J., Gallagher, V. C., \& Rossi, A. M. (2013). Impression management (IM) behaviors, im culture, and job outcomes. Journal of Managerial Issues.

Henseler, J., Ringle, C. M., \& Sarstedt, M. (2014). A new criterion for assessing discriminant validity in variance-based structural equation modeling. Journal of the Academy of Marketing Science, 43(1), 115-135. https://doi.org/10.1007/s11747-014-0403-8

Hsu, C. T., Yang, M. Y., \& Lai, H. F. (2011). The relationships between psychological contract breach and counterproductive work behaviors: Investigating the mediation and the moderated mediation effects. Academy of Management 2011 Annual Meeting - West Meets East: Enlightening. Balancing. Transcending, AOM 2011. https://doi.org/10.5464/AMBPP.2011.163.a

International Labour Organization. (2016). Workplace Stress: A collective challenge. In World Day for Safety and Health at Work (Issue April 2016). https://doi.org/10.1017/CBO9781107415324.004

Jones, E. E., \& Pittman, T. S. (1982). Towards a General Theory of Strategic Self-Presentation.pdf. Psychological Perspectives on the Self. https://doi.org/10.1111/j.1467-9558.2010.01385.x

Kahn, W. A. (1990). Psychological Conditions of Personal Engagement and Disengagement at Work. Academy of Management Journal. https://doi.org/10.5465/256287

Kimura, T., Bande, B., \& Fernández-Ferrín, P. (2018a). Work overload and intimidation: The moderating role of resilience. European Management Journal. https://doi.org/10.1016/j.emj.2018.03.002

Kimura, T., Bande, B., \& Fernández-Ferrín, P. (2018b). Work overload and intimidation: The moderating role of resilience. European Management Journal, 36(6), 736-745. https://doi.org/10.1016/j.emj.2018.03.002

Lamontagne, C. (2010). Intimidation: A Concept Analysis. https://doi.org/http://dx.doi.org/10.1111/j.1744-6198.2009.00162.x

Lara, P. Z. M. De. (2006). Fear in organizations: Does intimidation by formal punishment mediate the relationship between interactional justice and workplace internet deviance? Journal of Managerial Psychology. https://doi.org/10.1108/02683940610684418

Lazarus Theory. (2020). In Encyclopedia of Behavioral Medicine. https://doi.org/10.1007/978-3-03039903-0_301063

Mariwa, N. G., Betchem, G., Adu, I. A., \& Andrews, M. Y. (2021). The influence of spiritual leadership on turnover intention: assessing mediating role of quality of work life and moderating role of organization climate. Quantitative Economics and Management Studies. https://doi.org/10.35877/454ri.qems247

McMurray, A. J., Pirola-Merlo, A., Sarros, J. C., \& Islam, M. M. (2010). Leadership, climate, psychological capital, commitment, and wellbeing in a non-profit organization. Leadership and Organization Development Journal. https://doi.org/10.1108/01437731011056452

Musselman, L. J., MacRae, H. M., Reznick, R. K., \& Lingard, L. A. (2005). "You learn better under the gun": Intimidation and harassment in surgical education. Medical Education. https://doi.org/10.1111/j.1365-2929.2005.02247.x

Nadzam, D. M. (2009). Nursesrole in communication and patient safety. Journal of Nursing Care Quality. https://doi.org/10.1097/01.NCQ.0000356905.87452.62

Naru, A. S., \& Rehman, A. (2020). Impact of Job Insecurity and Work Overload on Employee Performance With the Mediating Role of Employee Stress: A Case of Pakistan's Fast-food Industry. International Journal of Human Resource Studies. https://doi.org/10.5296/ijhrs.v10i1.15741

Nixona, A. E., Mazzolab, J. J., Bauera, J., Kruegerc, J. R., \& Spectora, P. E. (2011). Can work make you sick? A meta-analysis of the relationships between job stressors and physical symptoms. Work and Stress. https://doi.org/10.1080/02678373.2011.569175

Organizational happiness index (OHI): conceptualization and operationalization of measurement among 
employees in services industry. (2016). Social and Management Research Journal.

Organizational Stress: A Review and Critique of Theory, Research, and Applications. (2012). In Organizational Stress: A Review and Critique of Theory, Research, and Applications. https://doi.org/10.4135/9781452231235

Penney, L. M., \& Spector, P. E. (2005). Job stress, incivility, and counterproductive work behavior (CWB): The moderating role of negative affectivity. Journal of Organizational Behavior. https://doi.org/10.1002/job.336

Prapanjaroensin, A., Patrician, P. A., \& Vance, D. E. (2017). Conservation of resources theory in nurse burnout and patient safety. Journal of Advanced Nursing. https://doi.org/10.1111/jan.13348

Rich, B. L., Lepine, J. A., \& Crawford, E. R. (2010). Job engagement: Antecedents and effects on job performance. Academy of Management Journal, 53(3), 617-635. https://doi.org/10.5465/amj.2010.51468988

Saks, A. M. (2006). Antecedents and consequences of employee engagement. Journal of Managerial Psychology. https://doi.org/10.1016/S0252-9602(17)30078-4

Schaufeli, W. B., Bakker, A. B., \& Salanova, M. (2006). The measurement of work engagement with a short questionnaire: A cross-national study. Educational and Psychological Measurement. https://doi.org/10.1177/0013164405282471

Shantz, A., Alfes, K., Truss, C., \& Soane, E. (2013). The role of employee engagement in the relationship between job design and task performance, citizenship and deviant behaviours. International Journal of Human Resource Management, 24(13), 2608-2627. https://doi.org/10.1080/09585192.2012.744334

Singh, J., \& Chopra, V. G. C. (2016). Relationship among workplace spirituality, work engagement and grit. Journal of Business and Management, 18(11), 21-27. https://doi.org/10.9790/487X1811032127

Sivan-Donin, D., Ben-Ezra, M., \& Hamama-Raz, Y. (2019). Quality or quantity of coping resources: Why not both? An integration of common stress theories. Psychiatry Research. https://doi.org/10.1016/j.psychres.2018.12.051

Su, F., Gao, H., Luo, Y., \& Luo, H. (2018). A Mediated Moderation Model of Work Overload and Mental Health of Professional Service Staff. 2018 15th International Conference on Service Systems and Service Management, $\quad$ ICSSSM 2018. https://doi.org/10.1109/ICSSSM.2018.8465010

Taylor, S. E., Repetti, R. L., \& Seeman, T. (1997). Health Psychology: What is an Unhealthy Environment and How Does It Get under the Skin? Annual Review of Psychology. https://doi.org/10.1146/annurev.psych.48.1.411

TRUONG, T. V. T., NGUYEN, H. V., \& PHAN, M. C. T. (2021). Influences of Job Demands, Job Resources, Personal Resources, and Coworkers Support on Work Engagement and Creativity. Journal of Asian Finance, Economics and Business. https://doi.org/10.13106/jafeb.2021.vol8.no1.1041

Uchechukwu, C., Ph, U., \& Subomi, A. (2020). Impact of Work Overload and Work Hours on Employees Performance of Selected Manufacturing Industries in Ogun State. 22(11), 16-25. https://doi.org/10.9790/487X-2211011625

Ugwu, F. O., \& Onyishi, I. E. (2020). The moderating role of person-environment fit on the relationship between perceived workload and work engagement among hospital nurses. International Journal of Africa Nursing Sciences. https://doi.org/10.1016/j.ijans.2020.100225

Zou, W., Zeng, Y., Peng, Q., Xin, Y., Chen, J., \& Houghton, J. D. (2020). The influence of spiritual leadership on the subjective well-being of Chinese registered nurses. Journal of Nursing Management. https://doi.org/10.1111/jonm.13106 